\title{
EEVA PUUMALA
}

\section{RAJOJEN BIOPOLITIIKKA: TIEDOLLINEN}

\section{ALTTIUS TURVAPAIKKAPUHUTTELUISSA ${ }^{1}$}

JOHDANTO

Rajojen ruumiillisella biopolitiikalla on keskeinen rooli maahanmuuttohallinnan täytäntöönpanossa. Rajojen biopolitiikalla tarkoitan politiikkaa, joka koskee erilaisten valvonnan ja hallinnan teknologioiden ja prosessien välityksellä tapahtuvaa elämän hallintaa valtion rajojen sisäpuolella ja jonka tuloksena syntyy hallinnoitava subjekti (esim. Foucault 1982; 2010; Helén 2016). Turvapaikkamenettelyssä muuttoliikkeiden hallinnoinnin politiikka sekä kansainvälinen ja kansallinen lainsäädäntö läpäisevät konkreettiset viranomaiskäytännöt. (Puumala ym. 2018b; myös Howell 2011). Mikrotason toiminta ei ole makrotasosta irrallista, vaikka tuota yhteyttä ei aina havaita tai siihen ei toiminnassa havahduta. Tässä tekstissä turvapaikkamenettely ilmentääkin sellaista hallinnan toteuttamista ja täytäntöönpanoa, joka perustuu olennaisilta osiltaan puhuttelutilanteiden aikaiseen kasvokkaiseen ruumiilliseen vuorovaikutukseen.

Turvapaikkamenettelyssä tutkitaan, kärsiikö hakija perustellusta vainon pelosta ja pystyykö hän tarvittaessa turvautumaan oman valtionsa suojeluun tai sisäisen paon mahdollisuuteen. Tämän tavoitteen tuloksekkuus riippuu olennaisesti puhuttelujen onnistumisesta. Puhuttelun hallinnollinen tarkoitus on saada hakijalta esiin riittävän omakohtainen kertomus, jonka perusteella hakijan yksilöllinen tarve kansainväliselle suojelulle voidaan arvioida.
Turvapaikkamenettely ei näin ollen ole rutiininomainen hallinnollinen viranomaisprosessi. Siinä on kyse sarjasta mikrotason käytäntöjä, joiden perusteella ruumiita joko rajataan valtiollisesta poliittisesta yhteisöstä ulos tai määritellään niiden oikeudet suhteessa valtioon. Tekstissä omaksuttu ymmärrys ruumiillisuudesta juontuu Jean-Luc Nancyn ruumiskäsityksestä (Nancy 2010; Puumala 2017; 2013). Nancylle ruumis osoittaa olemassaolon konkreettisuuden ja todellisuuden. Hänen ajattelunsa asettuu vastustamaan länsimaisessa teoriaperinteessä usein omaksuttua käsitystä ruumiin ja mielen erillisyydestä, identiteettien vakaudesta ja sen sijaan painottaa olemisen tapahtumista ja merkityksellistymistä ruumiiden välissä. Nancyn ruumiskäsitys koskettaa myös toiseuden ongelmaa: miten voimme tuntea toisen, kun toinen on aina irrallaan ja erillään itsestä, eikä toista siten koskaan voi tietää tai tuntea läpikotaisin. Tästä kumpuaa alttiuden ajatus olemassaoloa luonnehtivana tilana, jota pyritään valtakoneistojen välityksellä hallinnoimaan.

Turvapaikkamenettelyä luonnehtii tiedollinen epävarmuus, jota kutsun tässä artikkelissa alttiudeksi (myös Puumala 2017; 2013). Tiedollinen alttius juontuu mahdottomuudesta tuottaa tai saada esiin yhtä aikaa sekä objektiivisesti todennettavissa olevaa että kokemukseen pohjautuvaa tietoa. Kokemukset suodattuvat ja kommunikoidaan suhteisesti, jolloin niiden koettu merkityksellisyys ja niille annetut merkitykset elävät (Haddington, Mondada \& 
Nevile 2013; myös Maryns 2013, 676). Siten kokemuksiin pohjautuva tieto on luonteeltaan haavoittuvaa ja edellyttää väistämättä tulkintaa. Käsitteenä tiedollinen alttius pyrkiikin tuomaan esiin tiedon tilannekohtaisuuden sekä osapuolten toiminnalliset mahdollisuudet ja oikeudet tiedon tuottamiseen (ks. Stevanovic \& Peräkylä 2014). Tarkastelun keskiöön nousee tällöin turvapaikkamenettelyä läpileikkaava tiedollinen kamppailu, jonka ilmentymistapoihin puhuttelujen aikana kyseinen teksti pureutuu.

Turvapaikkamenettelyn tavoitteena oleva hakijan kansainvälisen suojelun tarpeen arviointi sisältää suuren määrän erilaisia käytänteitä, arviointeja ja tulkintaa (Puumala \& Kynsilehto 2015; Magalhaes 2016; Jubany 2013; Rogers ym. 2015; Puumala ym. 2018b). Menettelyyn sisältyvät mikrotason käytänteet toteuttavat paitsi kansainvälisen ja EU-oikeuden myös kansallisen lainsäädännön täytäntöönpanoa, jonka seurauksena tuotetaan hierarkkisia suojelun statuksia ja poliittisia subjektikategorioita (Puumala 2017; Mountz 2010). Suomalaisessa mittakaavassa historiallisen suuren turvapaikanhakijamäärän vuoksi uudistettu ja joulukuussa 2015 julkistettu hallituksen turvapaikkapoliittinen toimenpideohjelma (Valtioneuvosto 2015) esitti lukuisia linjauksia karsimaan "vetovoimatekijöitä", joiden ajateltiin houkuttelevan turvapaikanhakijoita Suomeen. Turvapaikkamenettelyyn kohdistui kasvavia tehokkuuspaineita, jotka heijastuivat puhuttelujen läpiviemiseen. Lisäksi hakijan asemaa heikennettiin oikeusapuun ja valitusaikoihin kohdennetuilla uudistuksilla.

Omassa tekstissäni lähestyn puhutteluja Maahanmuuttoviraston virkamiehen ja turvapaikanhakijan ruumiillisena kohtaamisena. Vaino- ja muuttokertomukset muodostetaan turvapaikkapuhuttelujen aikana monenkeskisessä vuorovaikutustilanteessa, jossa sekä neuvotellaan tiedollisista rajoista että ilmennetään ja tuotetaan poliittisia rajanvetoja (Puumala ym. 2018a). Turvapaikkakertomus muodostuu monen tekijän summasta. Sen kannalta merkityksellisiä ovat esimerkiksi hakijan traumati- soituminen ja tilanteen institutionaalinen sekä vuorovaikutuksellinen dynamiikka, puhutun ja kirjoitetun kielen eroavaisuudet ja kielellinen epätasa-arvo. Toisin kuin hallinnollinen viranomaiskäsitys antaa olettaa, puhuttelujen aikana muodostettava tieto ei edusta yksiselitteisesti hakijan omaelämäkerrallisia kokemuksia. Lopullisen kirjatun kertomuksen sisältöön ja muotoon vaikuttaa moni tekijä ja vain ani harvoin, jos koskaan, kirjattu kertomus välittää hakijan itsenäisesti muodostaman, muisteluun perustuvan kertomuksen. Hakijan - toisinaan myös tulkin - käsitys puhuttelun tarkoituksesta sekä viranomaisen odottaman kertomuksen luonteesta heijastuu turvapaikkakertomuksen sisältöön ja sen muotoon (Maryns 2013; myös Stevanovic \& Peräkylä 2014, 187 vuorovaikutustutkimuksellinen näkökulma ilmiöön).

Objektiivisuuteen pyrkivässä määritysprosessissa on siis vahva kokemuksellinen ja intersubjektiivinen ulottuvuus: prosessi on aina itsessään altis ja poliittinen, ja hallinnollinen tietoisuus tästä alttiudesta synnyttää helposti epäuskon ilmapiiriin. Keskeiseen asemaan nousee viranomaisen muodostama, välittynyt tulkinta siitä, miten hakijan tarina subteutuu ybtäältä lähtömaatietoon ja toisaalta kansainväliseen, eurooppalaiseen ja kansalliseen lainsäädäntöön, joilla suojelun saamista säädellään. Vaikka turvapaikkamenettely ei ole suoran poliittisen ohjauksen piirissä, valtionhallinnosta välitetty vetovoimatekijöiden minimoimisen ja hallinnan tehostamisen metaviesti johtavat helposti tilanteeseen, jossa arviointikriteerit muodostuvat tiukiksi ja turvapaikanhakijan kertomuksen uskottavuus ja autenttisuus asetetaan lähtökohtaisesti kyseenalaisiksi (Jubany 2011, 84; Herlihy ym. 2010; myös Saarikkomäki ym. 2018; Migri 2018). Tämä tiedon ja vallan yhteenkietoutuminen kääntää järjestelmän alttiuden hakijan kasvavaksi haavoittuvuudeksi ja korostaa hänen asemaansa määrittelyprosessin kohteena.

Vaino on abstrakti kategoria, jonka ilmentyminen ja ilmiasu saavat erilaisia muotoja, ja sitä myös ilmaistaan eri tavoin puhuttelujen 
aikana (Puumala ym. 2018a). Aina hakija ei myöskään jaa viranomaisen käsitystä hakemuksen ratkaisemisen kannalta olennaisista kokemuksista tai osaa joko sanallistaa tai edes merkityksellistää kokemuksiaan vastaamaan kertomuksen sisällölle asettettuja hallinnollisia odotuksia. Hakijat saattavat esimerkiksi kuvata yleistä kontekstia tarkasti, mutta sivuuttaa yksittäiset, heille tapahtuneet asiat vähäpätöisinä. Hakemuksen ratkaisussa keskeistä on yksilöllinen, perusteltu syy pelätä vainoa tai väkivaltaa, eikä viranomainen ole kiinnostunut yleisestä kontekstista, jonka arvioinnissa se luottaa olemassa oleviin maatietoraportteihin, YK:n pakolaisjärjestö UNHCR:n lausuntoihin tai muuhun objektiivisena pitämäänsä tietoon. Viranomaisen näkökulmasta hakijan kertomuksen paikkansapitävyys ja uskottavuus on todennettava, kun taas tietoisuus viranomaisen tekemän tulkinnan ensisijaisuudesta asettaa hakijan kerronnalle paineita ja saattaa osaltaan vaikuttaa siihen, että hakija pyrkii oikeuttamaan hakemuksensa merkittävänä pitämänsä yleisen kontekstin perusteella.

Puhuttelujen taustalla vaikuttaa oikeudellis-hallinnollinen tiedonintressi. Tulkinnan ymmärtäminen keskeiseksi osaksi turvapaikkamenettelyä nostaa esiin kysymyksen tiedon ja vallan suhteesta sekä tuon suhteen yhteydestä valtion harjoittamaan biopoliittiseen hallintaan. Turvapaikkapuhutteluja tutkinut Katrjin Maryns $(2013,662)$ määritteleekin puhuttelut kohtaamisiksi portinvartijan kanssa. Sellaisina niihin Marynsin mukaan sisältyy joukko rutiinikäytäntöjä, joiden kautta moninaisia ja keskenään erilaisia kertomuksia ja kerronnan tapoja tulkitaan suhteessa olemassa oleviin kriteereihin. Suojelun myöntämistä koskevat kriteerit, puhuttelun toteuttamisen tavat ja kokemuspohjaiset subjektiiviset kertomukset eivät kohtaa saumattomasti. Muistinvarainen kokemustieto ei lähtökohtaisesti ole yhteensopiva hallinnollisten kategorioiden, maatietoraporttien tai kansainvälistä suojelua koskevan ihmisoikeuslainsäädännön kanssa (ks. Zetter 1991; Perera 2006; Maryns 2013). Tässä tekstissä pureudun osapuolten välillä olevaan vahvaan tiedolliseen jännitteeseen, joka kulminoituu hakijan ruumiin kaksijakoiseen rooliin puhuttelujen aikana. Yhtäältä hakijan ruumis on väline arvioida kielellisen kertomuksen todenmukaisuutta, toisaalta se on vainon kokemukseen liitettyjen merkitysten välittäjä ja turvapaikkakertomuksen aktiivinen tuottaja.

Länsimaissa painotetaan vahvasti kielellistä ilmaisua tiedon välittämisessä. Painotus poissulkee vaihtoehtoiset tavat, joilla ihmiskeho voi paitsi muistaa myös kommunikoida yksilöllisiä ja kollektiivisia muistoja (Mallot 2006; Kearney 2007). Sanallisen kertomuksen painottaminen luonnehtii myös turvapaikkapuhutteluja, joissa hakijan suullisesti kertoma nähdään pääasiallisena keinona saada tietoa hänen kokemuksistaan. Kuitenkin viranomainen puhuttelujen aikana hyödyntää ja toisinaan myös kirjaa ylös havaintojaan hakijan käytöksestä, tunnereaktioista ja kehonkielestä (Puumala 2017; Puumala ym. 2018). Näitä havaintoja käytetään muun muassa ohjattaessa puhuttelun kulkua, tehtäessä tarkentavia kysymyksiä tai arvioitaessa hakijan esittämän suullisen kertomuksen uskottavuutta (Kynsilehto \& Puumala 2015; Puumala \& Kynsilehto 2015). Turvapaikkapuhutteluista keräämäni empiirinen aineisto osoittaa, että turvapaikkakertomus rakentuu myös ruumiillisen ilmaisun kautta. Etenkin kokemuksiin liitettyjä merkityksiä kommunikoidaan kehollisesti, mutta toisinaan kehonkieltä käytetään tuottamaan suhteita tai rakentamaan tapahtumakulkuja ja narratiivista koherenssia.

Turvapaikanhakijan ja viranomaisen välistä kommunikaatiota leimaavat monet rajoitteet. Osa näistä koskee osapuolten eriäviä käsityksiä lähtömaan tilanteesta, puhuttelun toteuttamisesta, osa liittyy kulttuurieroihin, kieli- ja tulkkausongelmiin ja osa puolestaan kumpuaa menettelyn taustalla piilevästä hallinnan logiikasta ja sen episteemisestä alttiudesta. Rajoitteet siirtyvät helposti osaksi päätöksentekoa vaikeuttaen tai hidastaen sitä tai äärimmäisissä tilanteissa jopa heikentäen hakijoiden oikeusturvaa (Jubany 2011). Aineistopohjaisten 
havaintojen johdattamana tämä teksti ottaa tarkasteluun yhteyden rajojen ruumiillisen biopolitiikan ja turvapaikkapuhutteluiden tiedollisten neuvottelujen ja kontrollin välillä. Miten kokemustietoa tuotetaan ja muotoillaan turvapaikkapuhutteluissa? Entä millaisia hallinnollisia käytänteitä menettelyn tiedollinen alttius tuottaa puhutteluihin? Ymmärrys näistä kysymyksistä on tarpeen aikana, jolloin turvapaikan hakemisesta keskustellaan laajasti suomalaisessa yhteiskunnassa ja menettelyn toimivuus on asetettu kyseenalaiseksi.

TURVAPAIKKAPUHUTTELU

TUTKIMUSKONTEKSTINA

Siinä missä Ihmisoikeuksien yleismaailmallisen julistuksen 14. artiklan mukaan turvapaikan hakeminen on jokaisen oikeus, on suojelun myöntäminen sitä tarvitsevalle valtioiden velvollisuus. Tämä nostaa suojelun tarpeen arvioinnin keskeiselle sijalle, ja tuon arvioinnin toteuttaminen on kansallisvaltioiden vastuulla. Suomessa prosessista vastaa Maahanmuuttovirasto. Se selvittää hakijan henkilöllisyyttä ja matkareittiä, hakemuksen perusteet, arvioi suojelun tarpeen sekä hakijan kertomuksen uskottavuuden ja tekee ratkaisun asiassa.

Arvioinnissa puhutteluilla on keskeinen asema, sillä ne ovat ensisijainen keino saada tietoa hakijan hakemuksen perusteista ja henkilökohtaisen perustellun pelon olemassaolosta. Sisällöllisesti puhuttelut jakautuvat kolmeen osaan: ensimmäisessä selvitetään hakijan identiteettiä ja asuinpaikkaa; toisessa keskitytään hakemuksen perusteiden selvittämiseen ja kolmas osa sisältää kaikille hakijoille esitettävät vakiokysymykset, jotka liittyvät muun muassa siihen, miten hakija suhtautuisi, jos hänet palautetaan kotimaahansa. Puhutteluiden aikana viranomainen laatii pöytäkirjan hakijan kertomuksesta. Puhuttelulle varataan aikaa noin kolme tuntia, mutta tarvittaessa pu- huttelua voidaan jatkaa pidempään tai hakijalle voidaan antaa toinen puhutteluaika riittävän selvityksen saamiseksi. Hakijan ja Maahanmuuttoviraston ylitarkastajan ohella puhutteluissa ovat läsnä (asioimis)tulkki ja mahdollisesti myös hakijan (oikeudellinen) avustaja. Puhuttelujen jälkeen Maahanmuuttovirasto pyytää tarvittavia lisäselvityksiä, kuten biometrisiä testejä, asiantuntijalausuntoja tai hakijan kotimaan dokumentteja. Hakijan turvapaikkapuhuttelussa esittämän kertomuksen uskottavuutta arvioidaan laaditun pöytäkirjan, lisäselvitysten ja lähtömaatiedon perusteella (vrt. Good 2004). Näin määritetään, onko hakijan pelko objektiivisesti perusteltua ja hakija suojelun tarpeessa.

Edellä esitetystä selvityksestä käy ilmi, että turvapaikkapuhuttelut ovat monikielisiä ja monenkeskisiä vuorovaikutustilanteita, joita luonnehtii tiedollinen hierarkia ja epätasa-arvo. Hakija on velvollinen tuottamaan asiassaan tietoa ja viranomaisella on oikeus esittää kysymykset. Lisäksi puhutteluissa kietoutuvat yhteen puhutun ja kirjoitetun kielen modaliteetit sekä niiden erot. Pöytäkirjat voivat nimittäin sekä korostaa että häivyttää elementtejä hakijan kertomuksesta. Koska puhuttelun aikana laadittu pöytäkirja muodostaa perustan hakemuksen yksilölliselle arvioinnille, haastattelukäytäntöjen lisäksi viranomaisen kirjaamiskäytännöillä onkin suuri tiedollinen merkitys. Pöytäkirjaan kirjatut seikat muodostuvat päätöksenteossa äärimmäisen näkyviksi, kun taas kirjaamatta jätetty tai mukautetusti kirjattu kertomus häivyttää hakijan kokemuksellista tietoa ja hänen tapahtumille antamiaan merkityksiä. Hakija ei voi varmasti tietää, uskooko häntä puhutteleva ylitarkastaja kuulemaansa tai näkemäänsä tai miten puhuttelupöytäkirjaa lukeva ylitarkastaja lukemaansa tulkitsee ja mihin muihin lähteisiin hän aikanaan päätöksensä perustaa. Viranomainen puolestaan ei koskaan voi olla täysin varma, että hakija kertoo totuuden ja pitäytyy omakohtaisten kokemustensa piirissä. 
Tutkimus turvapaikkamenettelystä on moninaista ja sitä tehdään useilla tieteenaloilla. Turvapaikkaviranomaisten roolia koskevissa tutkimuksissa on todettu, että kielimuuri, sosiaaliset stereotypiat, traumatisoituminen, kulttuuriset harhakäsitykset ja virheelliset oletukset käytöksestä, muistista ja totuuden kerrontatavoista vaikuttavat hakijoiden kertomasta tehtyihin tulkintoihin (esim. Jubany 2011; Magalhaes 2016; Kynsilehto \& Puumala 2015; Bayrak 2015; Herlihy ym. 2010; Herlihy \& Turner 2009; Rogers ym. 2015). Myös puhutun ja kirjoitetun kielen välisiä terminologisia ja rakenteellisia eroavaisuuksia on tutkittu turvapaikkapuhuttelujen kontekstissa (Blommaert 2001, 2006; Määttä 2015; Maryns 2013; Sigona 2014). Varsinaisia puhuttelutilanteita käsittelevissä tutkimuksissa puolestaan on tarkasteltu osapuolten välisiä diskursiivisia suhteita, puhujien asemia tai kielen muotoja ja rajoitteita (esim. Blommaert 2006; Maryns 2006, 2013; Pöllabauer 2004). Ei-kielellistä viestintää ja sen merkityksiä puhutteluissa on käsitelty pääasiassa liittyen uskottavuuden arviointiin ja menettelyn taustalla vaikuttaviin käsityksiin tiedosta (esim. Herlihy \& Turner 2009; Magalhaes 2016; Puumala \& Kynsilehto 2015; Abuya \& Mukundi 2006; Bögner ym. 2010; Bohmer \& Shuman 2007; Eades 2009; Kelly 1993; Shuman \& Bohmer 2004; Thomas 2006; Wettergren \& Wikström 2014; Wikström 2014). Monenkeskisestä vuorovaikutusdynamiikasta johtuvia tiedollisia neuvotteluja ja kontrollia on myös tarkasteltu tutkimuskirjallisuudessa, joskin muihin aihepiireihin verrattuna varsin vähän (Puumala ym. 2018a; Coutin 2001; Granhag ym. 2005).

Tässä artikkelissa esitän, että keskittymällä puhuttelun aikaiseen vuorovaikutukseen on mahdollista saada esiin tavat, joilla rajojen ruumiillinen biopolitiikka ja sen "tiedontahto" (Foucault 2010) muokkaavat konkreettisia puhuttelukäytänteitä. Erilaisten tiedonvälityksen ja kertomisen tapojen, eli kerronnan modaliteettien, huomiointi turvapaikkakertomusta rakentavina elementteinä vaikuttaa viranomaisen mahdollisuuteen arvioida tarinaa ja sen uskottavuutta. Analyysissäni en siis keskitykään pelkästään kielelliseen ilmaisuun, vaan empiirisen aineistoni pohjalta nostan esiin kokemuksellista kerrontaa luonnehtivat ruumiilliset modaliteetit ja tarkastelen niitä prosessin hallinnollis-poliittisen toimintalogiikan valossa. Tältä osin otan vaikutteita vuorovaikutustutkimuksen perinteestä, jossa huomioidaan myös vuorovaikutustilanteen ulkopuolisten ilmiöiden ja rakenteiden heijastuminen vuorovaikutuksen piirteisiin (esim. Stevanovic \& Peräkylä 2014).

Sekä hakijan asemaa luonnehtivaa että menettelyyn sisältyvää tiedollista alttiutta valottaakseni nojaan video- ja dokumenttiaineistoon, joka on kerätty Maahanmuuttoviraston suorittamista turvapaikkapuhutteluista vuosina 2014-2015. Tutkimusta varten videoitiin kuusi puhuttelua, joista laaditut puhuttelupöytäkirjat ja päätökset ovat myös osa aineistoa. Paneudun tässä artikkelissa ainoastaan yhteen puhutteluun, jolloin on paremmin nähtävissä, miten tiedollinen dynamiikka puhuttelun kulun aikana kehittyy ja läpäisee vuorovaikutustilanteen. Valitsemani esimerkit nostavat esiin erilaiset tietämiseen ja sen alttiuteen liittyvät toiminnot ja toimintajaksot, joiden kautta voidaan ymmärtää, miten osapuolet turvapaikan hakemista merkityksellistävät ja millaisia tiedollisia jännitteitä käsityserot tuottavat puhutteluihin. Yhdistämällä mikro- ja makrotaso voidaan tarkastella, miksi esimerkkipuhuttelussa tiedollisesti tapahtuu mitä siinä tapahtuu: millaisten rajojen ruumiillista biopolitiikkaa toteuttavien ja sen toimintaa vastustavien mikrokäytänteiden kautta tieto hakijan asiassa tuotetaan?

\section{TAVOITTEENA OBJEKTIIVINEN TIETO}

\section{JA AUTENTTINEN KERTOMUS}

Tässä luvussa avaan, miten pyrkimys objektiiviseen, todennettavissa olevaan tietoon ilmentyy 


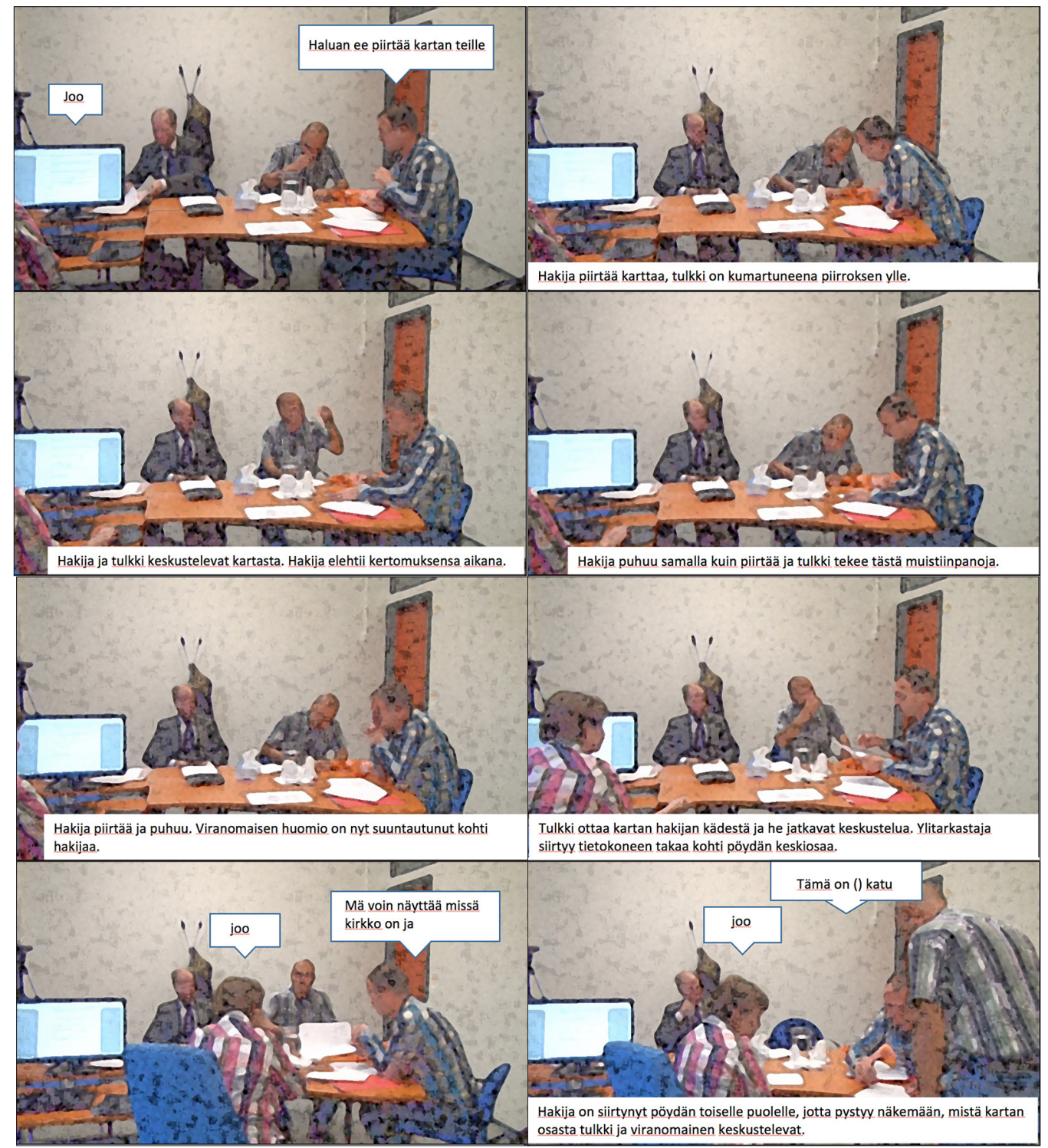

KUVA 1. KERTOMUS HAKIJAN KODIN YMPÄRISTÖSTÄ.

turvapaikkapuhutteluissa. Käsittelemässäni tapauksessa turvapaikanhakijan matka Suomeen on ollut kaikkea muuta kuin mutkaton: hän oli jättänyt kotimaansa jo vuonna 2000, vaikka turvapaikkapuhuttelu videoitiin syksyllä 2014. Tällä välin hakija oli asunut Turkissa ja Kreikassa paperittomana siirtolaisena. Migrin tiloissa pidetyssä puhuttelussa olivat läsnä arabiaa pu- huva, Irakista kotoisin oleva turvapaikanhakija, suomalainen ylitarkastaja ja asioimistulkki. Myös hakijan oikeudellinen avustaja oli paikalla puhuttelussa. Ylitarkastajaa lukuunottamatta kaikki läsnäolijat olivat miehiä.

Esimerkkiote on peräisin haastattelun ensimmäisestä, taustoittavasta osasta, jossa käsitellään hakijan identiteettiä ja asuinpaik- 
kaa lähtömaassa. Viranomainen istuu tietokoneen takana ja tulkki on sijoittuneena pöydän päähän. Ylitarkastajasta viistosti oikealle katsottuna pöydän vastakkaisella puolella istuu turvapaikanhakija, kun taas hakijan oikealla puolella istuu tämän oikeudellinen avustaja. Virkailija on juuri pyytänyt hakijaa kuvailemaan asuinaluettaan ja kotinsa ympäristöä Irakissa. Pyynnön taustalla vaikuttaa viranomaisen halu saada hakijalta tietoa, joka voidaan todentaa objektiivisiin lähteisiin nojaten ja jonka avulla voidaan varmistua, että hakija todella tulee kertomaltaan alueelta. Hakija vastaa ensin esittämällä varauksen, että koska hän on lähtenyt vuosia sitten, hän ei voi kuvailla mitään, mitä alueella on tapahtunut vuoden 2000 jälkeen.

Aikana,jolloin tämän tutkimuksen aineisto on kerätty, turvapaikanhakijalle voitiin myöntää kansainvälistä suojelua lähtöalueen perusteella, mikäli kyseistä aluetta pidettiin yleisesti turvattomana. Sittemmin Maahanmuuttoviraston käytäntö on muuttunut ja nykyisin suojelua voi saada vain perustuen yksilölliseen arviointiin: hakijan on kyettävä osoittamaan, että hän joutuisi todennäköisesti henkilökohtaisesti uhatuksi tai vainotuksi palatessaan. Viranomainen arvioi myös, voisiko hakija turvautua maansisäiseen pakoon kotimaassaan. Hakemuksen tutkintavaiheessa viranomainen arvioi puhuttelun aikana kerättyä ja tuotettua tietoa esimerkiksi lähtömaatietoa vasten ja muutoinkin tarkistaa yksityiskohtia hakijan kertomasta uskottavina ja luotettavina pitämistään lähteistä. Näin muodostuu arvio hakijan kertomuksen todenmukaisuudesta sekä siitä, onko hakijan kertomuksella tiedollista arvoa suhteessa asian ratkaisuun. Esimerkkiote alkaa, kun turvapaikanhakija esittää toiveen saada piirtää kartta virkailijalle (ruutu 1)

Turvapaikanhakijan alkaessa piirtää ylitarkastaja keskittyy ensin kirjaamistehtäväänsä ja tietokoneeseen ja vasta ruudun 5 kohdalla hänen huomionsa kiinnittyy hakijan toimintaan. Tällä välin turvapaikanhakija on puhunut itsekseen, elehtinyt suuntia ja selittänyt tulkil- le, mitä hän on piirtämässä. Tulkki on tehnyt muistiinpanoja hakijan piirtämästä kartasta ja tämän puheesta. Ruudussa 6 nähdään, miten tulkin ottaessa kartan hakijalta omiin käsiinsä ylitarkastaja oikeellisesti olettaa hakijan saaneen piirroksensa valmiiksi. Tämän seurauksena viranomainen siirtyy lähemmäs tulkkia, joka pitelee karttaa ja tarjoutuu selittämään virkailijalle, mitä karttaan on piirretty. Turvapaikanhakijan huomio on suunnattu ylitarkastajaan, ei karttaa pitelevään tulkkiin (ruutu 7). Hakija vaikuttaa olevan tietoinen siitä, että paikkansapitävä kuvaus hänen kotinsa ympäristöstä on elintärkeä hänen hakemuksensa uskottavuuden kannalta ja että arvio asiasta tullaan tekemään piirroksen perusteella. Hakija kiinnittää tarkasti huomionsa tulkin ja virkailijan väliseen kanssakäymiseen, ja pienen epäröinnin jälkeen pyytää lupaa lähestyä virkailijaa jotta hän voi myös nähdä kartan ja tarkistaa, että tulkin selitys siitä on moitteeton (ruutu 8). Hakijaa vaikuttaa kiinnostavan, miten hänen tarinansa välitetään ja miten viranomainen esitettyyn kertomukseen omalla toiminnallaan suhtautuu.

Hakija vaikuttaa olevan varsin hyvin selvillä niistä kriteereistä,joilla hänen kertomustaan arvioidaan. Tämä ilmenee sekä hänen asuinympäristönsä ajallista muutosta kohtaan esittämässään varaumassa että hänen halussaan tuottaa kirjallinen kuvaus aiemman kotinsa ympäristöstä. Turvapaikkapuhuttelut keskittyvätkin faktojen oikeellisuuteen, koskien paitsi sitä, mitä tietyssä maassa tapahtui, myös sen osalta, mikä hakijan rooli ja asema kyseisessä poliittisessa kentässä on ollut (Bohmer \& Shuman 2007, 609). Osapuolten asemaa luonnehtiva kielellinen epätasa-arvo vaikeuttaa kommunikaatiota hakijan ja viranomaisen välillä, sillä tulkki on tilanteessa ainoa, jolla on suora pääsy sekä hakijan että viranomaisen kertomaan. Tiedolliset jännitteet ovatkin puhuttelujen aikana suuret, mikä ilmenee ongelmina kommunikaation sujuvuudessa ja vaikeutena yhteensovittaa hakijan ja ylitarkastajan erilaisia tiedollisia tulokulmia. 
Useissa tutkimuksissa on todettu, että turvapaikkapuhutteluja ja -menettelyä luonnehtii epäuskon ja -luottamuksen ilmapiiri, jossa päähuomio toisinaan kohdentuu "ansiottomien" hakijoiden kiinnisaamiseen eikä suojelua tarvitsevien tunnistamiseen (Jubany 2011). Tässä asetelmassa alttius voidaan ymmärtää osapuolten tiedolliseksi asemaksi, joka paikantuu teoreettisen ja käytännöllisen välimaastoon ja josta kumpuaa erilaisia tilannesidonnaisia toimintoja, arvotuksia sekä valintoja (vrt. Neilson \& Rossiter 2008, käsitys prekaarisuudesta). Näin ymmärrettynä tiedollinen alttius ilmenee otteessa virkailijan hakijalle esittämässä pyynnössä kuvata kotinsa ympäristöä, jotta jokin osa hakijan kertomuksesta olisi todennettavissa objektiivisesti. Turvapaikkapuhutteluissa rajojen biopolitiikka ilmentyykin osapuolten välisinä, tiedon tuottamista ja tietämisen tapoja koskevina toimintoina ja toimintajaksoina. Osa näistä on kielellisiä, osa ruumiillisia ja osassa nämä kerronnan muodot sekoittuvat.

Otteesta ilmenee selvästi, ettei muistojen kommunikoiminen ja muistelu ole pelkästään kielellistä, vaan niihin liittyy olennaisina osina ruumiillisia, aistimuksellisia sekä kinesteettisiä komponentteja (ks. Herlihy \& Turner 2009). Esimerkin kertomukseen liittyy piirtäminen ja osapuolten institutionaalisesti määritelty sijoittuminen huoneeseen ja hakijan tähän tuottama muutos, kun hän siirtyy viranomaisen kanssa samalle puolen pöytää. Analyysini edetessä eikielellisellä viestinnällä voidaan nähdä olevan suuri rooli myös hakijan esittämän kokemustiedon kerronnallisen johdonmukaisuuden rakentumisessa. Ensin avaan kuitenkin ruumiin tiedollista merkitystä viranomaisen näkökulmasta.

\section{RUUMIS TODISTEENA VAINOSTA JA}

\section{VALHEESTA}

Ei-kielellistä viestintää pidetään usein kulttuurisidonnaisena sekä mahdottomana todentaa objektiivisesti (Herlihy \& Turner 2016; 2009; Magalhaes 2016). Myös Euroopan turvapaikka-asioiden tukiviraston (EASO 2014, 2015) turvapaikkapuhuttelua ja todistusaineiston arviointia koskevissa virallisissa oppaissa viranomaista ohjeistetaan olemaan tekemättä kertomuksen totuusarvoon liittyviä tulkintoja hakijan ei-kielellisen viestinnän tai hänen käytöksensä perusteella. Kuitenkin empiiriset tutkimukset turvapaikkaviranomaisten työstä ovat osoittaneet, että ruumis ja käytös ovat tärkeitä tekijöitä sekä puhuttelun läpiviemisessä että hakijan esittämän tarinan todenmukaisuuden ja uskottavuuden arvioimisessa (Jubany 2011; Kynsilehto \& Puumala 2015; Bayrak 2015). Vuorovaikutustutkimuksessakin tunteiden kommunikoinnilla ja esittämisellä on todettu olevan tiedollista merkitystä (Stevanovic \& Peräkylä 2014, 196-197).

Koska turvapaikanhakijoilla on hyvin harvoin todistusaineistoa, joka aukottomasti todentaisi heidän kertomuksensa, yksilöllisen suojelun tarpeen arviointi perustuu pitkälti puhuttelussa esitetyn kertomuksen laadun ja sisällön arviointiin (Herlihy ym. 2010). Viranomainen voi kuitenkin pyytää hakijan asiassa erilaisia lisäselvityksiä. Näihin lukeutuvat muun muassa hakijan ruumiiseen kohdistetut biometriset testit sekä lääketieteelliset lausunnot ja tutkimukset, joille hakija voidaan altistaa suullisen kertomuksen uskottavuuden arvioimiseksi (Heinemann ym. 2015). Suvendrini Pereraa (2006: 638) mukaillen hakijat ovat menettelyssä todistamisen ja todistelun välimaastossa. Ruumista voi arvioida valheen paljastamiseksi tai hyödyntää kertomuksen todentamiseksi, ja se myös tuottaa kertomusta vainosta.

Hakijan esittämän kertomuksen kanssa yhdenmukaiset ruumiin vammat, kuten arvet tai röntgenkuvin dokumentoidut murtumat, voivat turvapaikkamenettelyssä toimia todisteina koetusta väkivallasta, kuten seuraava ote kuvaa. Esimerkki on otettu puhuttelun toisesta osasta, jossa hakijan tulee esittää perusteet turvapaikkahakemukselleen. Haki- 


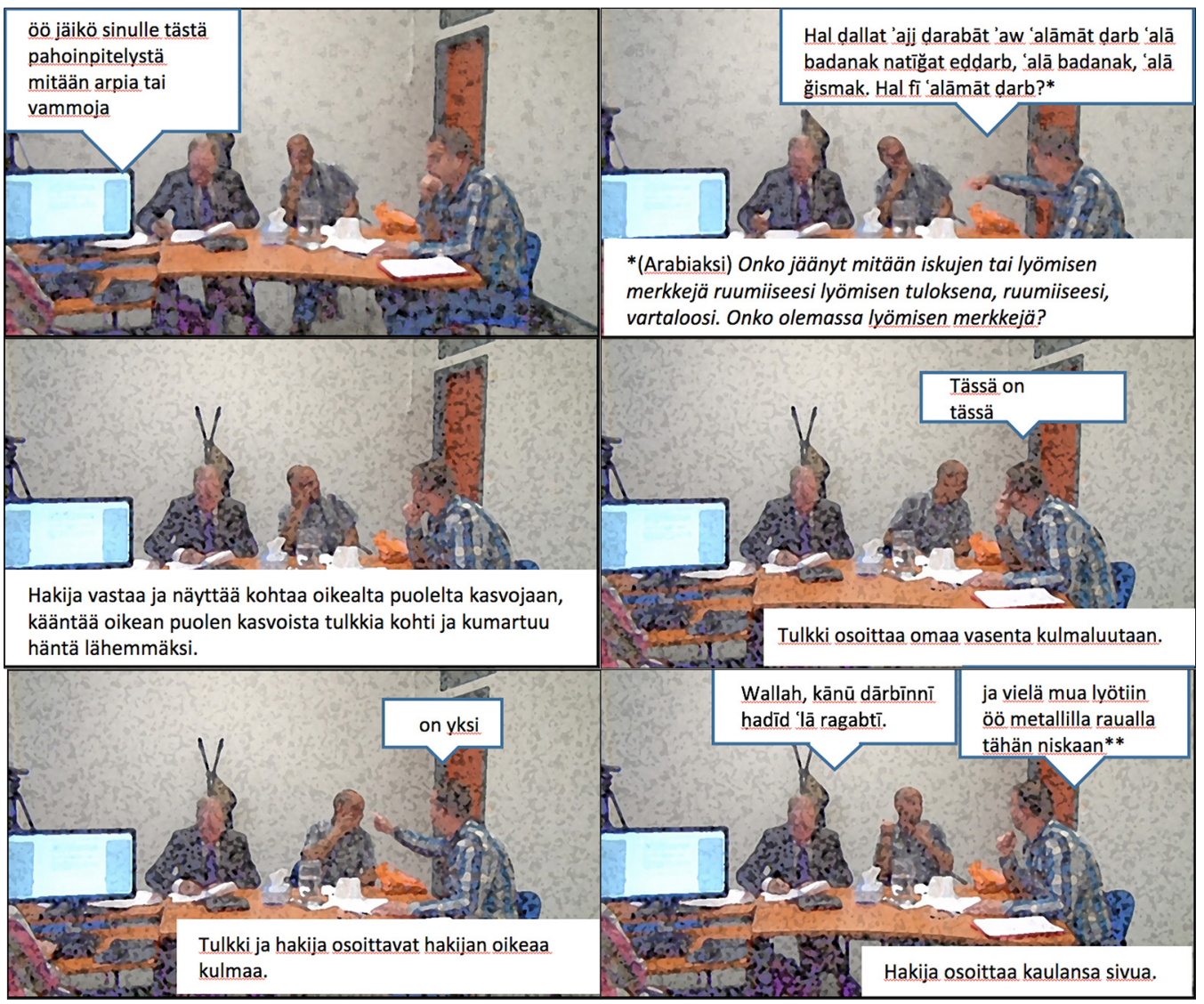

KUVA 2. RUUMIILLISET TODISTEET VÄKIVALLASTA.

jan kertomus on ennen otetta ollut varsin ylimalkainen, ja ylitarkastaja onkin pyytänyt hakijaa kertomaan tarkemmin elämästään ja toimeentulostaan Turkissa. Hakija on alkanut kuvailla vuosia jatkunutta epävarmaa tilannettaan paperittomana siirtolaisena Turkissa: hän on joutunut asumaan kadulla ilman majoitusta, tekemään työtä "laittomasti" ja häneen on kohdistunut kaltoinkohtelua sekä fyysistä väkivaltaa. Hakija on kertonut, että hän ei myöskään aina saanut palkkaa työstään, koska hänellä ei ollut esittää työnantajalleen passia. Kerrottuaan nämä seikat hakija painottaa, ettei yritä herättää puhuttelijan myötätuntoa, vaan haluaa ainoastaan kertoa miten asiat ovat olleet. Hakija asemoi näin kertomansa eksplisiittisesti episteemisen järjestyksen piiriin: tiedon alueelle (Stevanovic \& Peräkylä 2014, 198). Tämän jälkeen hän täsmentää, että kerran hän joutui suuren ihmisjoukon pahoinpitelemäksi vain, koska oli pyytänyt korvausta tekemästään työstä. Ylitarkastaja dokumentoi hakijan sanoman pöytäkirjaan, minkä jälkeen hän pyytää lisätodisteita, jotka todentaisivat hakijan esittämän kertomuksen. Tätä tarkoitusta varten viranomainen kysyy, onko pahoinpitelystä jäänyt hakijan kehoon arpia tai vammoja (ruutu 1).

Otteessa viranomaisen kysymystä motivoi puhuttelujen institutionaalinen tavoite, eli pyrkimys saada esiin objektiivista todistusaineistoa, joka tukisi turvapaikanhakijan esittämää tarinaa. Mahdollisesti se, että tulkki kysymystä tulkatessaan osoittaa hakijaa päästä varpaisiin 
ja takaisin, myös saa hakijan tulkitsemaan ylitarkastajan kysymyksen tässä tiedollisessa kontekstissa (ruutu 2). Hakijan vastaus suuntautuu niiden ruumiinosien indikoimiseen, joihin on jäänyt merkkejä lyönneistä: oikea kulmaluu/karva ja kaula (ruutu 3). Ruuduissa 4-5 tulkki edelleen suuntautuu tarkastajan asettamaan tehtävään käyttäen sekä omaa että hakijan kehoa todistusaineistona osoittamalla ensin omaa kulmakarvaansa ja sitten hakijan kulmakarvaa kohdistaakseen ylitarkastajan huomion arpeen. On merkillepantavaa, että ruudun 4 sanallisessa käännöksessä tulkki ei suoraan nimeä kohtaa, jossa arpi on, vaan käyttää deiktistä ilmaisua "tässä on tässä" ja pakottaa näin viranomaisen irrottamaan katseensa tietokoneen ruudulta välitetyn viestin ymmärtämiseksi. (Ks. myös Puumala ym. 2018a.)

Otteessa turvapaikanhakijan sanallisesti välittämä informaatio on kiinteästi yhteydessä elekieleen eikä hänen kertomuksensa rakennu puhutun kielen piirteiden varaan kokemuksen ja sen seurausten välittämiseksi viranomaiselle (Blommaert 2001; Maryns 2013). Eleitä, tunnetiloja ja ei-kielellisiä viestejä on kuitenkin mahdotonta tulkita ja niiden merkitystä purkaa irrallaan asiayhteydestä, jossa ne esitetään. Turvapaikkakertomuksissa vaino ja erilaiset väkivaltakokemukset muotoillaan suhteessa niiden nostattamiin osin ruumiillisiin ja aistimuksellisiin tulkintoihin, jotka ovat aina konteksti- ja tilannesidonnaisia (vrt. Berard 2006, 237; Connolly 2010, 182-183). Monitulkintaisuus ei kuitenkaan poista ruumiin merkittävyyttä kokemuksiin liitettyjen tulkintojen ja merkitysten välittäjänä sekä monenkeskisten neuvottelujen ja positionaalisuuksien näkyväksi tekijänä. Ei-kielellisellä viestinnällä ja vuorovaikutteisilla käytänteillä onkin merkittävä rooli lopullisen turvapaikkakertomuksen rakentamisessa, mutta osapuolten välisestä valtahierarkiasta johtuen viranomaisella on oikeus tulkita niiden merkitys haluamallaan tavalla tai jättää se huomiotta.

Esimerkissä hakijan ruumis toimii materiaalisena todistusaineistona kerrotun ko- kemuksen totuudellisuudesta. Ruumiillisen todistusaineiston käyttö ja huomioiminen ei kuitenkaan ole systemaattista. Turvapaikkamenettelystä keräämässäni aineistossa ylitarkastajat ovat joissakin tapauksissa kirjanneet hakijoiden tunnetilat tai havaintonsa hakijan käytöksestä puhuttelupöytäkirjoihin. Kuitenkaan tämä käytäntö ei ole edes yhden puhuttelun sisällä systemaattinen siten, että kaikki kohdat, joissa hakija esimerkiksi itkee, miettii tai epäröi vastata, olisi merkitty näkyviin. Aineistosta ei myöskään suoraan ole selvää, miksi joissain hakijoiden turvapaikkaperusteita käsittelevissä kohdissa itkuisuus tai epäröinti on kirjattu ylös, kun taas toisissa kohdissa näin ei ole tehty. Käsitteellisellä tasolla ilmiö voidaan ymmärtää tiedollisen alttiuden kautta: hakija tuottaa tietoa kokemuksistaan tai kokemusten saamat merkitykset ilmentyvät ruumiin välityksellä, mutta viranomaisen hallinnollisesta tulkintakehyksestä johtuen kaikkia reaktioita ei vastaanoteta tiedollisesti relevantteina.

Koska järjestelmällinen kirjaamiskäytäntö puuttuu, tulee vain osa hakijan tunnetiloista tai käytöksestä näkyväksi ja siksi tiedollisesti mahdollisesti merkitseväksi, kun taas osa eikielellisestä viestinnästä häviää näkymättömiin ja menettää merkityksensä kertomuksen rakentajana. Myöskään kattavaa ohjeistusta ruumiillisen viestinnän tulkitsemisesta kertomuksen rakentajana ei ole. Kun näiden seikkojen ohella otetaan vielä huomioon, että päätöksen tekevä ja puhutteleva ylitarkastaja voivat olla kaksi eri henkilöä, korostuu turvapaikkamenettelyn uskottavuusarvioinnin alttius tiedollisille vääristymille tai virhetulkinnoille.

\section{NEUVOTTELU TOIMINNAN}

\section{MERKITYKSISTÄ JA OLOSUHTEISTA}

Turvapaikanhakijuuteen ja pakolaisuuteen liittyy olennaisena osana jaksoja, joiden ai- 


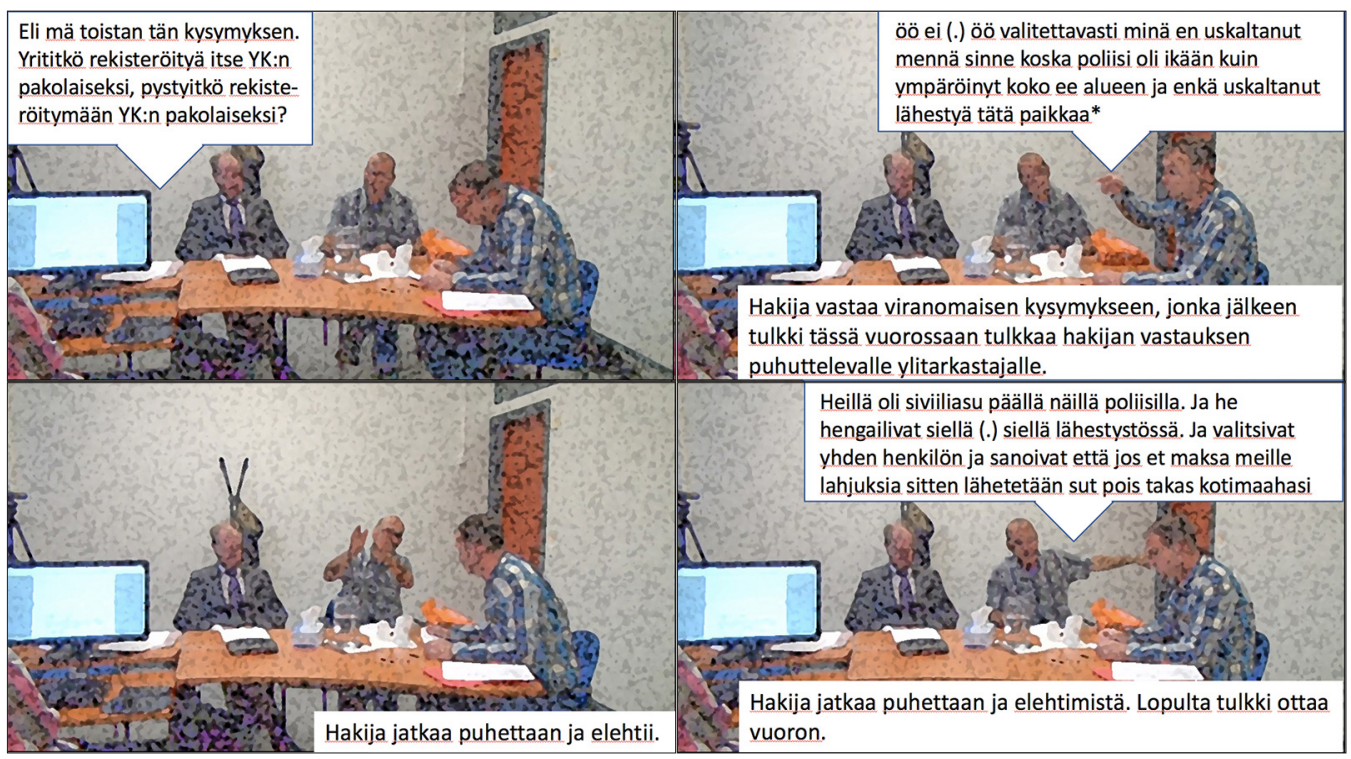

KUVA 3. TILANTEINEN YMMÄRRYS TOIMINTAMAHDOLLISUUKSISTA JA SEN KOMMUNIKOINNIN HAASTEET.

kana ruumiin liike taukoaa tai pysähtyy. Tämä liikkumisen logiikka ei vastaa viljalti levitettyä kuvaa eurooppalaisiin kohdemaihin määrätietoisesti pyrkivistä pakolaisista ja ihmisten "virroista" (Mountz 2010; McNevin 2017). Esimerkkipuhuttelun kohdalla hakijan siirtymävaihe lähtömaasta Suomeen on ollut hyvin pitkäkestoinen, yli kymmenen vuoden mittainen, ja pitänyt sisällään oleskelua useassa "kauttakulkumaassa". Turvapaikkamenettelyn kannalta tässä tilanteessa on keskeistä selvittää, voisiko hakija turvautua kauttakulkumaan antamaan suojeluun sen sijaan, että hänen hakemuksensa tutkittaisiin Suomessa. Tämä kuvastaa pyrkimystä ratkaista, mille valtiolle liikkuva keho "kuuluu" ja mikä valtio on hakemuksen käsittelystä vastuussa. Tiedonmuodostus turvapaikanhakijan kokemuksista ja niiden suhteesta esimerkiksi lähtömaatietoon tai kauttakulkumaihin ei kuitenkaan ole ongelmatonta.

Seuraavassa esimerkissä hakijan kertomus turvapaikkaperusteistaan on katkennut viranomaisen tiedusteluun, onko hakija pyrkinyt hakemaan suojelua Turkista. Maahanmuuttovirasto pitää Turkkia turvallisena kol- mantena maana, joten hallinnollisen logiikan näkökulmasta hakijan ei olisi koskaan pitänyt saapua Suomeen asti. Ennen otteessa 3 esitettyä keskustelua ylitarkastaja on tiedustellut hakijalta, onko tämä rekisteröitynyt YK:n pakolaisjärjestön pakolaiseksi oleskellessaan Turkissa. Hakija ei kuitenkaan anna suoraa vastausta kysymykseen, vaan aloittaa yksityiskohtaisen selonteon Turkin poliisivoimissa vallitsevasta korruptiosta ja siitä kuinka huonosti poliisi on kohdellut pakolaisia YK:n pakolaisjärjestön toimipisteen lähellä. Tulkin puheenvuoron aikana hakija tarkkailee virkailijan toimintaa tämän kirjatessa ylös hakijan selontekoa: hakijan katse on kiinnittyneenä ylitarkastajaan ja koska hän nojautuu ylävartalollaan eteenpäin kohti viranomaista, myös hakijan kehollinen orientaatio on suunnattu häneen.

Kirjattuaan hakijan vastauksen ylitarkastaja korostaa toistavansa aiemman kysymyksensä (ruutu 1), vaikka hän tosiasiassa muotoilee sitä hieman toisin ja painottaa uudessa kysymyksessään yrittämistä ja pystymistä (ruutu 1). Näin hän ilmaisee olevansa tyytymätön hakijan antamaan selontekoon ja antaa ym- 
märtää, että hän odottaa saavansa suoran vastauksen kysymykseensä.

Esimerkkiotteessa hakija ja viranomainen käyvät dynaamista tiedollista neuvottelua hakijan tekemien valintojen merkityksestä ja hänen toimintaedellytyksistään tietyssä tilanteessa. Otetta edeltävä, viranomaisen vältteleväksi tulkitsema vastaus tuo esiin emotionaalisen ja toiminnallisiin oikeuksiin liittyvän deonttisen järjestyksen välillä olevan jännitteen (ks. Stevanovic \& Peräkylä 2014, 196-198). Ensimmäisessä vastauksessaan hakija kuvaili Turkin poliisivoimien harjoittamaa mielivaltaa ja näin kutsui puhuttelevaa viranomaista jakamaan käsityksen ahdingosta. Tämä vetoomus tulee kuitenkin torjutuksi, kun ylitarkastaja pitäytyy tiukasti deonttisen järjestyksen piirissä ja esittää kysymyksensä uudelleen. Viranomaisen toistokysymys kuitenkin avaa myös mahdollisuuden hakijan ei-odotuksenmukaisen toiminnan oikeuttamiselle: ylitarkastaja käyttää verbejä yrittää ja pystyä (ks. Puumala ym. 2018b). Hakija ei edelleenkään vastaa suoraan kieltävästi viranomaisen kysymykseen, vaan hän arvioi välttämättömäksi suhteuttaa lopullinen kieltävä vastauksensa yleiseen tilanteeseen. Hakijan vastauksena kysymyksiin antama seikkaperäinen selonteko onkin ymmärrettävissä perusteluksi, jonka avulla hakija selittää, miksi hän on toiminut toisin kuin mitä viranomaisen näkökulmasta looginen ja mahdollinen toimintatapa antaa olettaa. Myös hakijan jälkimmäinen vastaus toistaa ensimmäisen selonteon, vaikkakin tuottaa myös viranomaisen toivoman yksiselitteisen ei-vastauksen.

Vastauksillaan hakija havainnollistaa kuilua viranomaisen näkökulmasta johdonmukaisen toimintatavan ja hakijan kohtaaman todellisuuden välillä. Hakijan vastaus luo pohjan myös ymmärrykselle siitä, kuinka kohdattu todellisuus on lopulta johtanut elämään paperittomana siirtolaisena Turkissa. Hakijan vastaukset suhteutuvat yhtäältä hänen Turkissa tekemäänsä omakohtaiseen tulkintaan Turkin poliisin toiminnasta. Tämän tulkinnan kommunikoinnissa ei-kielellisen viestinnän ja eleiden merkitys kerronnan omakohtaisuudelle, sen sisäisen koherenssin rakentumiselle ja tapahtumiin liitetyille merkityksille vaikuttaa otteessa keskeiseltä (ruudut 3-4; vrt. Kendon 2005, 127-198). Toisaalta hakijan vastauksessa heijastuu puhuttelutilanteessa tehty tilannesidonnainen tulkinta hänelle esitetyn kysymyksen suhteesta puhuttelujen tavoitteeseen ja puhutteluissa vallitsevaan epäuskon ilmapiiriin, jossa hakijan sanomaa ja ruumista koko ajan arvioidaan (Jubany 2011; Herlihy \& Turner 2009). Tilannesidonnaisuus ei merkitse, että vuorovaikutus olisi yksinomaan turvapaikkamenettelyn institutionaalisen kontekstin muotoilemaa ja määrittämää. Sen sijaan kontekstin merkityksiä muotoillaan sekä niistä neuvotellaan vuorovaikutuksessa (ks. esim. Heritage 2012). Otteen kuvaamassa neuvottelussa hakijan tuottamat vastaukset asettuvat epäsuorasti vastustamaan virkailijan esittämien kysymysten taustalla piilevän yksilökeskeisen hallinnollisen logiikan toimintaa. Vastaukset tuottavat toisenlaisen tiedollisen tulokulman toimintamahdollisuuksiin ja niiden arviointiin.

Turvapaikkapuhuttelujen tiedon tuottamista koskevat mikrokäytänteet osoittavat, että rajojen ruumiillista biopolitiikkaa täytäntöönpannaan ja sen toimintaa vastustetaan tilannesidonnaisesti ruumiillisissa suhteissa. Hakijan kannalta merkittävä tieto ei välttämättä ole viranomaisen näkökulmasta relevanttia ja päinvastoin. Kun hakijat välittävät kokemuksiaan ja niille antamiaan merkityksiä, he usein kyseenalaistavat hallinnollisen ymmärryksen relevantista tiedosta turvapaikkahakemuksen ratkaisemisessa. Tämä johtaa otteessa esitetyn kaltaisiin tilanteisiin, joissa viranomainen kokee hakijan välttelevän vastaamista. Puhuttelujen aikana käydäänkin jatkuvaa neuvottelua tiedollisesta auktoriteetista ja tiedollisista asemista sekä tuotetun kertomuksen tiedollisesta merkityksestä. Toimintajakso kokonaisuutena havainnollistaa puhuttelujen aikana tuotetun tiedon 
alttiutta ja tekee näkyviksi hakijan esittämän kertomuksen merkityksistä käytävät neuvottelut ja kokemuksiin pohjautuvien valintojen todentamisen vaikeudesta syntyvät vuorovaikutuskäytännöt.

\section{RUUMIILLINEN KERTOMUS JA SIIHEN}

\section{KIINNITETYT MERKITYKSET}

Arvioinnin kohteena olemisen ohella hakijan ruumis on myös turvapaikan hakemiseen ja sen perusteisiin liitettyjen affektiivisten merkitysten ja merkityksellisyyden välittäjä. Affektiivisen merkityksen ja merkityksellisyyden ymmärtämisessä nojaudun Liina Soinnun (2018, 95-96) tulkintaan affektiivisista käytännöistä. Soinnun mukaan affektiivisen käytännön käsite kuvaa toimintaa, jossa ruumiillinen ja diskursiivinen yhdistyvät ja jossa osapuolten välisestä epätasa-arvosta johtuen henkilökohtainen, aistimuksellinen ulottuvuus sekä vallankäyttö punoutuvat yhteen. Affektiivinen merkitys ja merkityksellisyys auttavat ymmärtämään turvapaikanhakijan tekemiä henkilökohtaisia tulkintoja ja niiden ilmaisuja. Nämä merkitykset ja merkityksellistämisen tavat ilmentyvät ruumiin ja kielen vuorovaikutuksessa tai pelkästään ruumiillisten toimintojen välityksellä.

Turvapaikanhakija-identiteetti, jolla tässä tarkoitan turvapaikan tarvitseruuden ilmaisemisen ja turvapaikan ansaitsevuuden arvioinnin välistä dynamiikkaa, rakentuu affektiivisen toiminnan välityksellä vuorovaikutuksessa. Tiedon, arvioinnin ja kontrollin välinen rajankäynti on läsnä puhutteluissa ja niiden keskinäinen dynamiikka heijastuu paitsi käytäntöihin, joilla kertomusta tuotetaan, myös kriteereihin, joita vasten tuotettua kertomusta arvioidaan. Jokaiseen viranomaisen esittämään kysymykseen on olemassa useampi mahdollinen vastaus, ja ne kaikki voivat edustaa hakijan kokemusta, kokemukseen liitettyjä henkilökohtaisia ja laajempia yhteiskunnallisia tulkintoja sekä hakijan kokemukselle antamia merkityksiä. Turvapaikan hakemiseen kytkeytyy myös hyvin intiimejä yhteyksiä, jotka vaikeuttavat hakemuksen perustelemista puhtaasti subjektiivisista lähtökohdista.

Hakijan näkökulmasta turvapaikan tarvetta ei välttämättä voida yksiselitteisesti eristää hänen suhteistaan ja yhteyksistään toisiin, merkityksellisiin ihmisiin (vrt. Despret 2013). Kuten seuraava esimerkki osoittaa, hakemukselle esitettävät perusteet rakentuvat näin ollen yhtäältä suhteessa puhuttelutilanteen ilmentämään hallinnolliseen prosessiin ja toisaalta tilanteessa välittömästi ja välillisesti läsnä oleviin ihmisiin (myös Stevanovic \& Peräkylä 2014, 192-193).

Hakija on ennen otteen alkua kuvaillut pitkällisesti lukuisia väkivaltakokemuksiaan ja häneen kohdistuneita uhkauksia, jotka ovat värittäneet hänen ja hänen lapsuudenperheensä elämää kotimaassa. Hän on myös kuvannut paperittomuudesta kummunnutta perustavanlaatuista epävarmuutta, joka on leimannut hänen arkeaan sekä Turkissa että Kreikassa. Hakijan kertomukseen on sisältynyt lisäksi tapahtumakuvauksia häneen kohdistuneista rasistisista hyökkäyksistä ja pahoinpitelyistä Kreikassa. Koko tämän kerronnan ajan hänen puheensa on ollut rauhallista, eikä siinä ole esiintynyt merkkejä tunnekuohuista. Juuri ennen esimerkkiotteen alkua virkailija on kehottanut hakijaa vielä kiteyttämään syyn, miksi hänelle pitäisi myöntää turvapaikka Suomesta.

Hakijan esittämä peruste saattaa ensin vaikuttaa parhaimmillaankin yhdentekevältä: hakija nimittäin ryhtyy puhumaan puolisostaan ja tämän pojasta ja lopulta toteaa epäsuorasti, että hänen poikapuolensa hyvinvoinnin ja tulevaisuudennäkymien turvaaminen ovat toimineet turvapaikan hakemista motivoivina tekijöinä. Hakijan tulkinta hänelle esitetystä kysymyksestä on ei-odotuksenmukainen. Samalla hänen ruumiillisen reaktionsa voimakkuus kertoo vastaukselle annetusta painoarvos- 


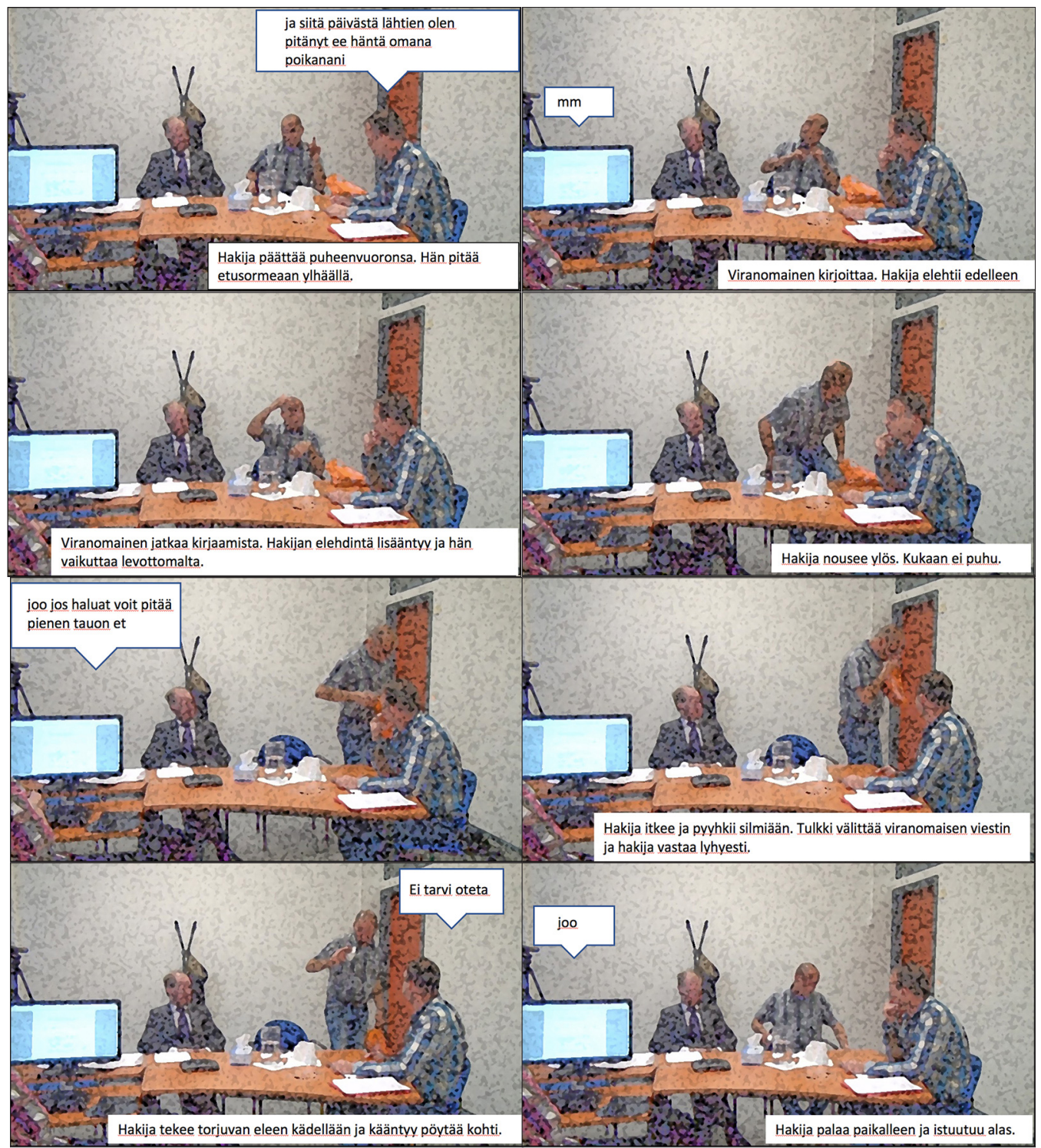

KUVA 4. AFFEKTIIVISET MERKITYKSET JA NIIDEN ILMENTYMINEN PUHUTTELUISSA.

ta ja asian merkittävyydestä hakijalle itselleen. Pelkkä poikapuolen mainitseminen aiheuttaa hakijassa voimakkaan affektiivisen reaktion ja hän alkaa itkeä (ruutu 4). Viranomaisen näkökulmasta hakijan olisi tullut tässä yhteydessä korostaa häneen systemaattisesti kohdistunutta vainoa ja väkivaltaa, joka on yhtäältä johtanut päätökseen lähteä kotimaasta ja toisaalta tehnyt mahdottomaksi turvautua suojelun hakemiseen Turkista tai Kreikasta. Otteessa hakijan turvapaikkaprosessille asettamat toiveet perheen yhdistämisestä ja niiden toteutumisen epävarmuus ilmenevät tunnekuohuna ja hakija etäännyttää itsensä kertomuksestaan ja puhuttelutilanteesta nousemalla ylös ja kääntämällä selkänsä virkailijalle (ruudut 3-6). Sitä, 
pitääkö virkailija hänen tuskaansa aitona, ei voida aineistosta havaita.

Hakijan tunnereaktion voimakkuus - itku, johon liittyy hakijan nouseminen seisomaan ja kääntyminen selin muihin läsnäolijoihin joka tapauksessa häiritsee puhuttelun rutiininomaista etenemistä ja saa aikaan vastareaktion virkailijalta, joka ehdottaa hakijalle taukoa (ruutu 5). Hakija ei kuitenkaan myönnä, etteikö hän pystyisi jatkamaan ja sekä sanallisesti että elehtien vakaasti kieltäytyy keskeyttämästä tarinaansa: hän haluaa jatkaa, mutta on toisaalta pakottanut puhuttelevan ylitarkastajan ottamaan hänen affektiivisen ja ruumiillisen viestinsä vastaan (ruutu 7). Hakijan reaktiot ja toiminta viestittävät hänen näkökulmastaan merkityksellisintä syytä turvapaikan hakemiseen. Samalla hakijan toiminta tuo esiin osapuolten erilaiset tulokulmat tilanteeseen ja korostaa eroavaisuutta tilaisuuden saamissa merkityksissä. Nuo merkitykset paitsi ohjaavat kysymyksenasettelua, myös vaikuttavat annettujen vastausten sisältöön, muotoon ja sävyihin.

Hallinnollisesti ja oikeudellisesti hakijan esimerkissä kertoma peruste, joka tuotettiin hakijan omana perusteena turvapaikan tarpeelle, ei ole relevantti tai oikeuta suojelun saamiseen. Sen sijaan hakijan puhuttelun aikana kuvailema väkivalta ja vaino muodostavat vahvat perusteet kansainvälisen suojelun tarvetta arvioitaessa. Hakijalle itselleen ne eivät kuitenkaan olleet merkittävimpiä elementtejä, vaan hänen pahin pelkonsa oli se, että hänen lapsipuolensa joutuisi kohtaamaan ja käymään läpi saman kuin hän. Hakijalle lapsen sosiaalisten, koulutuksellisten ja taloudellisten tarpeiden turvaaminen näyttäytyi tärkeämpänä kuin oman asemansa turvaaminen. Esimerkki havainnollistaa, että käsitykset perustellusta vainon pelosta ja sen tarkoituksenmukaisesta ilmaisemisesta ovat jatkuvan neuvottelun kohteina turvapaikkapuhuttelujen aikaisessa vuorovaikutuksessa (Kynsilehto \& Puumala 2015). Tämän huomiotta jättäminen voi johtaa virheellisiin olettamuksiin siitä, millaiset kokemukset ovat relevantteja ja millaisilla viesteillä on ilmaisuvoimaa ihmisten historian, kokemusten ja suhteiden esiintuomisessa (Berard 2006: 245).

Jos pyrimme ymmärtämään turvapaikanhakijoiden lähtöä motivoivia tekijöitä tai arvioimaan heidän suojelun tarvettaan, on tärkeä hahmottaa, miten laaja tekijöiden ja olosuhteiden kirjo lopulta vaikuttaa ilmiön taustalla. Viranomaisen olisi tehtävässään annettava tilaa hakijan omien merkitysten ja tulkintojen ilmaisemiselle, vaikka ne hakemuksen arvioinnin kannalta vaikuttaisivat merkityksettömiltä. Jos tätä ei ymmärretä, on olemassa riski, että laajempi hakemuksen taustalla oleva henkilöhistoriallinen konteksti poistetaan tai sen ilmaukset tulkitaan hakijan haitaksi arvioimalla hakemus ilmeisen perusteettomaksi. Turvapaikan hakeminen on usein suhteinen teko. Siihen sisältyy yhtäältä tulkintoja esimerkiksi lähtömaan poliittisista, uskonnollisista ja etnisistä suhteista, mutta usein lähtöpäätöstä motivoivat myös toisenlaiset, paljon intiimimmät suhteet ja yhteydet.

Esimerkkinä toimineessa puhuttelussa hakija ei monin paikoin (otteet 3 ja 4) osannut kertoa turvapaikan hakemisen syistään siten kuin viranomainen sitä edellytti. Kertomuksessa välitetyn tiedon ymmärtäminen edellyttääkin viranomaiselta puhutteluvaiheessa kertomisen edellytysten luomista ja ylläpitoa ja arviointivaiheessa subjektiivista tulkintaa ja tilannekohtaista harkintaa. Lisäksi se edellyttää laveaa ymmärrystä siitä, millaiset seikat ovat hakijan omakohtaisessa kertomuksessa tärkeitä ja millaisin keinoin hakija ylipäätään kertomustaan kommunikoi puhuttelujen aikana. Kokemukset ja niihin liitetyt merkitykset voivat sanallisen kertomuksen lisäksi tai sijasta ilmentyä ruumiillisina toimintoina, tunnereaktioina sekä eleinä (Puumala ym. 2018a; myös Damasio 2000; Kendon 2005). Oman aineistoni perusteella etenkin traumaattisten tapahtumien ja väkivaltakokemusten kuvailu saattaa olla verbaalisesti niukkaa, kun taas sanaton viestintä voi samassa tilanteessa olla hyvin runsasta. 


\section{JOHTOPÄÄTÖKSET}

Turvapaikkakertomuksen muodostumisen haasteita voidaan ymmärtää Jerome Brunerin eletyn elämän, koetun elämän ja kerrotun elämän välille tekemän erottelun avulla. Eletty elämä liittyy toteutuneeseen tapahtumavirtaan, kun taas koetulla elämällä Bruner viittaa tapahtumiin yhdistettyihin merkityksiin ja tulkintoihin. Kerrottu elämä puolestaan tarkoittaa kokemusten kontekstisidonnaista esittämistapaa (sit. Herlihy \& Turner 2009). Siten turvapaikkapuhutteluissa odotetun "omakohtaisen", "riittävän yksityiskohtaisen" ja "kattavan" tapahtumakuvauksen muotoileminen suulliseksi kertomukseksi ei ole yksinkertaista ja vaatii navigointia kaikkien kolmen osa-alueen välillä. Hakijan mahdollinen traumatisoituminen, merkitysten kulttuurisidonnaisuus sekä tilanteiden monenkeskisyys ja monikielisyys sekä kielellinen epätasa-arvo vaikeuttavat kokemustiedon välittämistä entisestään.

Turvapaikkamenettelyä luonnehtiva tiedollinen alttius näyttäytyy syvästi kontekstisidonnaisina vuorovaikutteisina ja ruumiillisina käytänteinä puhuttelujen aikaisissa toiminnoissa ja toimintajaksoissa. Tiedontahdon ja vallankäytön välinen dynamiikka läpäisee menettelyn. Hakijoilla ei kuitenkaan ole mahdollisuutta arviointivaiheessa vaikuttaa kertomuksesta syntyneeseen tulkintaan, jolloin viranomaisen arvio saa tiedollisen etusijan. Nojautumalla yhteen puhutteluun olen osoittanut, miten prosessiin sisäänrakennettu tiedollinen alttius ja kokemusperäisen varman tiedon mahdottomuus heijastuvat puhuttelun eri vaiheisiin, tiedon välittämisen tapoihin sekä laajempaan suojelun tarpeen arviointiin. Kysymys ei ole pelkästään siitä, miten tietoa välitetään. Kyse on myös siitä, mille annetaan tiedollinen arvo ja miten tuota arvoa arvioidaan prosessin eri vaiheissa.

Hakijan turvapaikkapuhuttelun aikana antamien vastausten merkitys muodostuu osapuolten puhetekojen, tilanteessa vaikut- tavien erilaisten tietämisen tapojen, kanssakäymisen modaliteettien sekä hallinnollisen tiedonmuodostusprosessin välimaastossa. Päätöksentekovaiheessa viranomainen arvioi hakijan esittämää kokemustietoa suhteessa kansalliseen ja kansainväliseen lainsäädäntöön sekä viranomaisten toimintaa ja tulkintaa suuntaaviin ohjeistuksiin. Näin syntyy tulkinta siitä, ilmentääkö hakijan subjektiivisiin kokemuksiin perustuva kertomus objektiivisesti perusteltua pelkoa, joka oikeuttaa turvapaikkaan. Turvapaikkamenettelyjen osalta rajojen ruumiillinen biopolitiikka liittyy maahanmuuton hallintapyrkimykseen, jossa arvioinnin kohteeksi asetetaan yksittäinen ruumis. Biopoliittinen hallinta ei tässä tapauksessa koske valtion ulkorajoilla tapahtuvaa rajakontrollia, vaan ilmentyy tavalla, jossa sisä- ja ulkopuolen välinen raja hämärtyy. Vaikka hakijan ruumis on valtion sisäpuolella, se voidaan vielä menettelyn kautta palauttaa rajojen ulkopuolelle. Tarvittaessa hallinta voidaan ulottaa jopa hakijan ruumiin sisäpuolelle, solutasolle, sillä hakijan kertomusta voidaan todentaa esimerkiksi DNA-testein (Helén 2016; Heinemann ym. 2015).

Siten turvapaikkamenettelyssä toiminnallistuva rajojen ruumiillinen biopolitiikka läpäisee sekä ilmaisu-, tulkinta- että arviointivaiheet. Siksi kysymykset episteemisestä auktoriteetista, tiedollisesta vallankäytöstä, tiedon muodostamisesta sekä sen tulkinnoista käytävä kamppailu korostuvat myös varsinaisissa puhutteluissa. Menettelyä itsessään luonnehtiva tiedollinen alttius koskee vaikeutta - ehkä jopa jonkinasteista mahdottomuutta - sovittaa hakijoiden kertomukset yksiselitteisesti ja aukottomasti yhteen 'objektiivisen' lähtömaatiedon, raporttien sekä asiantuntijalausuntojen kanssa. Prosessin alttius puolestaan kääntyy hakijan tiedolliseksi alttiudeksi. Tästä havainnosta kumpuaa ymmärrykseni tiedollisesta alttiudesta molempien osapuolten asemaa luonnehtivana episteemisenä positiona, joka muovaa toimintoja ja vuorovaikutuskäytänteitä puhutte- 
lutilanteissa. Puhuttelujen aikaiset käytänteet auttavat ymmärtämään, miten kansainvälisen suojelun saamisen kriteerit ja valtioiden pyrkimys hallita maahanmuuttoa toiminnallistuvat. Turvapaikkamenettelyssä on näin ymmärrettynä kyse poliittisen yhteisön rajoista, niistä käytävistä neuvotteluista ja niiden tuottamisesta suhteessa yksittäiseen ruumiiseen. Menettely punoo yksilölliset tunteet ja kehot yhteen tiedon ja uskomusten poliittis-hallinnollisten rakenteiden kanssa.

Kuten tässä artikkelissa olen osoittanut, turvapaikkakertomuksen tuottaminen on monivaiheinen ja väärinkäsityksille altis prosessi. Siihen sisältyvät kamppailun ja neuvottelun hetket auttavat ymmärtämään, miten tiivis suhde ihmisruumiin ja valtiollisten hallinnan käytänteiden välillä vallitsee. Esimerkit osoittavat, että ei-kielellinen ilmaisu on kanava, jonka kautta hakijat tuottavat syvyyttä ja sisältöä kerronnalleen ja jolla on siten keskeinen rooli turvapaikkahakemuksen perusteiden ilmentämisessä (myös Haddington ym.2013). Käsitykseni sopii hyvin yhteen neurotieteellisessä tutkimuksessa esitetyn näkemyksen kanssa, jonka mukaan kokemukset eivät ole ensisijaisesti kielellisiä. Tunne- ja aistipohjaiset elementit ovat merkittävä osa tapahtumista kertomista ja niiden merkityksellistämistä. (Damasio 2000.) Niiden huomiointi ja käyttö tiedollisina resursseina ei kuitenkaan ole turvapaikkapuhutteluissa systemaattista.

Turvapaikkapuhutteluissa keskeistä on paitsi se, kärsiikö hakija perustellusta vainon pelosta, myös se, miten tämä pelko tulisi ilmaista haastattelussa, jotta se tulisi tunniste-

\section{VIITTEET}

1. Tutkimusta on rahoittanut Suomen Akatemia (SA266009). Haluan kiittää tutkimukseen osallistuneita turvapaikanhakijoita sekä Maahanmuuttoviraston ylitarkastajia, tulkkeja sekä lakimiehiä, jotka ovat antaneet suostumuksensa tutkimuksen toteuttamiselle. Keskustelut Simo K.Määtän,Hanna-Leena Ristimäen tuksi ja kirjatuksi tietona. Jos rajojen ruumiillisen biopolitiikan ja sen hallinnollisen logiikan rooli turvapaikkaprosessissa häivytetään, voi turvapaikkamenettely helposti näyttäytyä politiikasta täysin irrallisena hallinnollisena käytäntönä. Tällöin on riskinä, että prosessin ongelmat nähdään kysymyksenä yksittäisen virkamiehen toiminnasta tai hallintoviraston organisaatiokulttuurista eikä niiden laajempaa yhteyttä maahanmuuttohallintoon ja sen poliittisiin tavoitteisiin tunnisteta.

Artikkelin laajempana tavoitteena on herättää kysymys suojelun saavutettavuudesta. Tässä yhteydessä saavutettavuus ei liity siihen, onko turvapaikkahakemuksen jättäminen mahdollista, vaan tapaan, jolla turvapaikkajärjestelmä on valjastettu toimimaan, ja tilanteeseen, jossa sen käytännöt eivät välttämättä tunnista tai osaa suhteuttaa hakijan kertomaa logiikkaan, johon kertomus pohjautuu. Tällöin on riskinä, että hakijan kertomuksen virheellinen tulkinta johtaa suojelun tarpeen tunnistamatta jäämiseen. Vastuu tästä on valtiolla, sillä sen on kansainvälisen oikeuden mukaan myönnettävä turvapaikka suojelua tarvitsevalle. Riskin järjestelmän mahdollisesta virheestä kantaa kuitenkin yksittäinen hakija. Tässä tutkimuksessa käytettävissä olevan aineiston perusteella on mahdotonta arvioida, missä määrin tämä johtaa virheellisten päätösten tekemiseen. Jos tavoitteena olisi oikeudenmukaisempi, hakijan osallisuutta kasvattava ja tehokkaampi menettely, puhuttelutilannetta luonnehtiva tiedollinen alttius ja sen vaikutukset kertomuksen kirjaamiseen ja arvioimiseen olisi otettava huomioon menettelyä kehitettäessä.

sekä Riitta Ylikomin kanssa ovat olleet tärkeitä argumentin kehittämisessä. Lämmin kiitos lisäksi Liisa Häikiölle, Henna Luoma-Halkolalle, Katja Maununaholle sekä kahdelle arvioitsijalle käsikirjoitusta koskevista kommenteista. 


\section{KIRJALLISUUS}

Abuya, Edwin \& Mukundi, George (2006)”Assessing asylum claims in Africa: Missing or meeting standards?". Netherlands International Law Review 53:2, 171-204.

Bayrak, Sule (2015) Contextualizing discretion: microdynamics of Canada's refugee determination system. Département de science politique, Faculté des arts et des sciences. Montréal: University of Montréal.

Berard, Tim (2006) "From concepts to methods: On the observability of inequality". Journal of Contemporary Ethnography 35:3, 236-256.

Blommaert, Jan (2001) "Investigating narrative inequality: African asylum seekers' stories in Belgium”. Discourse E̊ Society 12:4, 413-449.

Blommaert, Jan (2006) "How legitimate is my voice? A rejoinder". Target 18:1, 163-176.

Bögner, Diana; Christopher Brewin \& Jane Herlihy (2010) "Refugees' experiences of Home Office interviews: A qualitative study on the disclosure of sensitive personal information”. Journal of Ethnic and Migration Studies 36:3, 519-535.

Bohmer, Carol \& Shuman, Amy (2007) "Producing epistemologies of ignorance in the political asylum application process". Identities: Global Studies in Culture and Power 14:5, 603-629.

Connolly, William (2010) "Materialities of experience". Teoksessa Coole, Diana ja Samantha Frost (toim.) New Materialisms: Ontology, Agency, and Politics. Durham, NC: Duke University Press, 178-200.

Coutin, Susan (2001) "The oppressed, the suspect, and the citizen: Subjectivity in competing accounts of political violence". Law E Social Inquiry 26:1, 63-94.

Damasio, Antonio (2000) The Feeling of What Happens: Body and Emotion in the Making of Consciousness. New York: Mariner Books.

Despret, Vinciane (2013) "Responding bodies and partial affinities in human-animal worlds". Theory, Culture Eे Society 30:7-8, 51-76.

Eades, Diana (2009) “Testing the claims of asylum seekers: The role of language analysis". Language Assessment Quarterly 6:1, 30-40.

European Asylum Support Office (2014) EASO Practical Guide: Personal Interview. EASO Practical Guides Series, December 2014. Saatavissa: https://easo.europa.eu/wp-content/uploads/EASO-Practical-Guide-
Personal-Interview-EN.pdf. Luettu 21.2.2018.

European Asylum Support Office (2015). EASO Practical Guide: Evidence Assessment. EASO Practical Guides Series, March 2015. Saatavissa: https://www.easo. europa.eu/sites/default/files/public/EASO-PracticalGuide_-Evidence-Assessment.pdf. Luettu 21.2.2018.

Foucault, Michel (1982) "The subject and power". Critical Inquiry 8:4, 777-795.

Foucault, Michel (2010) Seksuaalisuuden bistoria: Tiedontabto. Nautintojen käyttö. Huoli itsestä. Suomentanut Kaisa Sivenius. Helsinki: Gaudeamus.

Good, Anthony (2004) "Expert evidence in asylum and human rights appeals: an expert's view". International Journal of Refugee Law 16:3, 358-380.

Granhag, Pär, Leif Strömvall \& Maria Hartwig (2005) "Granting asylum or not? Migration board personnel's beliefs about deception". Journal of Ethnic and Migration Studies 31:1, 29-50.

Haddington, Pentti; Lorenza Mondada \& Maurice Nevile (2013) Interaction and Mobility: Language and the Body in Motion. Berlin \& Boston, MA: Walter De Gruyter. Helén, Ilpo (2016) Elämän politiikat: Yhteiskuntatutkimus Foucault'n jälkeen. Helsinki: Tutkijaliitto.

Heritage, John (2012) "Epistemics in action: Action formation and territories of knowledge". Research on Language and Social Interaction 45, 1-29.

Herlihy, Jane \& Stuart Turner (2009) "The Psychology of Seeking Protection". International Journal of Refugee Law 21:2, 171.

Herlihy, Jane \& Stuart Turner (2016) "Emotions and the assessment of credibility". Teoksessa Convay, Heather \& John Stannard (toim.) Emotional Dynamics of Law and Legal Discourse. London \& Oxford: Bloomsbury, Kindle edition.

Herlihy,Jane; Kate Gleeson \& Stuart Turner (2010) "What assumptions about human behavior underlie asylum judgments?" International Journal of Refugee Law 22:3, 351-366.

Howell, Alison (2011) Madness in International Relations: Psychology, Security, and the Global Governance of Mental Health. London \& New York: Routledge.

Jubany, Olga (2011) "Constructing truths in a culture of disbelief: Understanding asylum screening from within”. International Sociology 26:1, 74-94.

Kearney, Richard (2007) "Narrating Pain: The Power of Catharsis". Paragraph: A Journal of Modern Critical 
Theory 30:1, 51-66.

Kelly, Nancy (1993) "Gender-related persecution: Assessing the asylum claims of women". Cornell International Law Journal 26, 625-674.

Kendon, Adam (2005) Gesture: Visible Action as Utterance. Cambridge: Cambridge University Press.

Kynsilehto, Anitta \& Eeva Puumala (2015) ”Persecution as experience and knowledge: the ontological dynamics of asylum interviews". International Studies Perspectives 16:4, 446-462.

Määttä, Simo (2015) "Interpreting the discourse of reporting: The case of screening interviews with asylum seekers and police interviews in Finland". Translation E Interpreting 7:3, 21-35.

Magalhaes, Bruno (2016) "The Politics of Credibility: Assembling Decisions on Asylum Applications in Brazil”. International Political Sociology 10:2, 133-149.

Mallot, Edward (2006) "Body politics and the body politic". Interventions: The International Journal of Postcolonial Studies 8:2, 165-177.

Maryns, Katrijn (2006) The Asylum Speaker: Language in the Belgian Asylum Procedure. Manchester \& Northampton: St. Jerome Publishing.

Maryns, Katrjin (2013) "Disclosure and (re)performance of gender-based evidence in an interpreter-mediated asylum interview". Journal of Sociolinguistics 17:5, 661-686.

McNevin, Anne (2017) "Learning to live with irregular migration: towards a more ambitious debate on the politics of 'the problem'". Citizenship Studies 21:3, 255-274.

Migri (2018) Irakiin palanneen turvapaikkaa hakeneen tapaus julkisuudessa. http://migri.fi/artikkeli/-/asset_ publisher/irakiin-palanneen-turvapaikkaa-hakeneentapaus-julkisuudessa?p_p_auth=sEdsKya0

Mountz, Alison (2010) Seeking Asylum: Human Smuggling and the Bureaucracy at the Border. Minneapolis \& London: University of Minnesota Press.

Nancy,Jean-Luc (2010) Corpus. Kääntänyt Susanna Lindberg. Kokoelmassa Filosofin sydän. Helsinki: Gaudeamus.

Neilson, Brett \& Ned Rossiter (2008) "Precarity as a political concept, or, Fordism as an exception". Theory, Culture E' Society 25:7-8, 51-72.

Perera, Suvendrini (2006) '”They give evidence': Bodies, borders and the disappeared". Social Identities: Journal for the Study of Race, Nation, and Culture 12:6, 637-656.
Pöllabauer, Sonja (2004) "Interpreting in asylum hearings: Issues of role, responsibility and power". Interpreting 6:2, 143-180.

Puumala, Eeva (2013) "Politiikan tuntu, mieli ja merkitys: Tapahtuva yhteisö ja poliittisen kokemus kehollisissa kohtaamisissa”. Tiede Eं edistys 38:2, 125-138.

Puumala, Eeva (2017) Asylum seekers, sovereignty, and the senses of the international: A politico-corporeal struggle. London \& New York: Routledge.

Puumala, Eeva \& Anitta Kynsilehto (2015)”Does the body matter? Determining the right to asylum and the corporeality of political communication". European Journal of Cultural Studies, DOI: 10.1177/1367549415592898.

Puumala, Eeva; Hanna-Leena Ristimäki \& Riitta Ylikomi (2018b, tulossa) "Kokemus, kertominen ja tieto turvapaikkapuhutteluissa". Teoksessa Lyytinen, Eveliina (toim.) Turvapaikanhaku ja pakolaisuus Suomessa: tutkimuksia tilallisista ja ajallisista muutosprosesseista. Siirtolaisuusinstituutti: Turku.

Puumala, Eeva; Riitta Ylikomi \& Hanna-Leena Ristimäki (2018a) "Giving an account of persecution: The dynamic formation of asylum narratives". Journal of Refugee Studies 31:2, 197-215.

Rogers, Hannah; Simone Fox \& Jane Herlihy (2015)"The importance of looking credible: the impact of the behavioural sequelae of post-traumatic stress disorder on the credibility of asylum seekers". Psychology, Crime E० Law 21:2, 139-155.

Saarikkomäki, Elsa; Nea Oljakka, Johanna Vanto, Elina Pirjatanniemi, Juha Lavapuro \& Anne AlvesaloKuusi (2018). Kansainvälistä suojelua koskevat päätökset Maahanmuuttovirastossa 2015-2017. Pilottitutkimus 18-34-vuotiaita Irakin kansalaisia koskevista myönteisistäja kielteisistäpäätöksistä. Oikeustieteellisen tiedekunnan tutkimusraportteja ja katsauksia 1/2018. Saatavilla osoitteessa: <http://www.utu.fi/fi/yksikot/law/tutkimus/katsauksia-ja-tutkimusraportteja/Documents/ Kansainvalista\%20suojelua\%20koskevat\%20paatokset\%20Maahanmuuttovirastossa\%2022.3.2018.pdf >. Luettu 29.5.2018.

Shuman, Amy \& Carol Bohmer (2004) "Representing trauma: Political asylum narrative". The Journal of American Folklore 117:466, 394-414.

Sigona, Nando (2014) "The Politics of refugee voices: representations, narratives, and memories”. Teoksessa Fiddian-Qasmiyeh, Elena; Gil Loescher, Katy Long \& 
Nando Sigona (toim.) The Oxford Handbook of Refugee and Forced Migration Studies. Oxford: Oxford University Press. 369-382.

Sointu, Liina (2018) "Slipping into 'that nurse's dress': Caring as affective practice in mixed-sex couples' relationships". Teoksessa Tuula Juvonen \& Marjo Kolehmainen (toim.) Affective Inequalities in Intimate Relationships. London: Routledge, 95-108.

Stevanovic, Melisa \& Anssi Peräkylä (2014) "Three orders in the organization of human action: On the interface between knowledge, power and emotion in interaction and social relations". Language in Society 43:2,185-207.

Thomas, Robert (2006)"Assessing the credibility of asylum claims: EU and UK approaches examined". European Journal of Migration Law 8, 79-96.

Valtioneuvosto (2015) Hallituksen turvapaikkapoliit- tinen toimenpideohjelma. 8.12.2015. Luettavissa https://valtioneuvosto.fi/documents/10184/1058456/ Hallituksen+turvapaikkapoliittinen+toimenpide ohjelma+8.12.2015/98990892-c08e-4891-8c230d229f1d6099. Luettu 9.11.2018.

Wettergren, Åsa \& Wikström Hanna (2014) "Who is a refugee? Political subjectivity and the categorization of Somali asylum seekers in Sweden". Journal of Ethnic and Migration Studies 40:4, 566-583.

Wikström, Hanna (2014) "Gender, culture and epistemic injustice: The institutional logic in assessment of asylum applications in Sweden". Nordic Journal of Migration Research 4:4, 210-218.

Zetter, Roger (1991) "Labelling Refugees: Forming and Transforming a Bureaucratic Identity". Journal of Refugee Studies 1,39-62. 